\title{
PENGARUH PENDEKATAN QUANTUM LEARNING TERHADAP HASIL BELAJAR MATEMATIKA
}

\author{
Nia Susilawati ${ }^{1}$, Dewi Silviana ${ }^{*}$, Mutmainnah ${ }^{1}$ \\ ${ }^{1}$ Program Studi Pendidikan Matematika, STKIP Bima \\ *Email korespondensi: dewiatrian2015@yahoo.com
}

\begin{abstract}
ABSTRAK
Tujuan yang ingin dicapai dalam penelitian ini adalah untuk mengetahui seberapa besar manfaat pendekatan quantum learning terhadap hasil belajar matematika materi pokok fungsi dan persamaan kuadrat pada kelas X SMA Negeri 2 Sape Tahun Pelajaran 2017/2018. Adapun rancangan penelitian yang digunakan penelitian ini adalah quasi experiment, yaitu metode eksperimen yang pengontrolannya dilakukan terhadap satu variabel saja, yaitu variabel yang dipandang paling dominan dalam quasi eksperimen, kontrol atau pengendalian variabel tidak bisa dilakukan secara penuh. Sampel diambil secara simple random sampling yaitu sampel di ambil secara sengaja dan tidak acak Sehingga diambil 2 kelas yaitu siswa kelas $X^{1} 25$ orang siswa dan $X^{2} 25$ orang siswa sehingga berjumlah 50 . Berdasarkan hasil perhitungan secara statistik diperoleh nilai t hitung sebesar $=3,779$, maka $t$ tabelnya pada taraf signifikansi $5 \%=2,011$. Karena nilai t hitung lebih besar $t$ tabel maka hipotesis nol (Ho) ditolak yang diajukan dalam penelitian ini yaitu "Pengaruh pendekatan quantum learning terhadap hasil belajar matematika materi pokok fungsi dan persamaan kuadrat pada kelas X SMA Negeri 2 Sape Tahun Pelajaran 2017/2018" ditolak sedangkan hipotesis altematif $\left(\mathrm{H}_{\mathrm{a}}\right)$ yang berbunyi "Pemberian tugas rumah efektif dalam meningkatkan Hasil belajar matematika pada pokok bahasan fungsi persamaan kuadrat siswa kelas X semester I di SMA Negeri 2 Sape Tahun Pelajaran 2013/2014 diterima. Pada taraf signifikasi (taraf kepercayaan) $5 \% \mathrm{t}_{\text {hitung }}>\mathrm{t}_{\text {tabel }}=3,779>2,011$.
\end{abstract}

Kata Kunci : Quantum Learning, Hasil Belajar

\begin{abstract}
The objectives to be achieved in this study were to find out how much the quantum learning approach benefits the mathematics learning outcomes of the subject matter of functions and quadratic equations in class X of Sape 2 Senior High School in Academic Year 2018/2019. The research design used in this study is quasi experiment, which is an experimental method whose control is carried out on only one variable, namely the variable that is considered the most dominant in quasi-experimental, control or variable control cannot be done in full. Samples were taken by simple random sampling, ie the samples were taken intentionally and not randomly so that 2 classes were taken, namely students of class X1 25 students and X2 25 students so that there were 50 students. Based on the results of statistical calculations obtained by the value of $t$ count $=3.779$, then $t$ table at the significance level of $5 \%=2.011$. Because the value of $t$ count is greater than $t$ table, the null hypothesis (Ho) is rejected which is proposed in this study, namely "The effect of the quantum learning approach on the mathematics learning outcomes of the subject matter and the quadratic equation in class X Sape 2 Academic Year 2017/2018" rejected while the alternative hypothesis (Ha) which reads "Giving home assignments is effective in improving mathematics
\end{abstract}


learning outcomes on the subject of the function of the quadratic equation of class X students in semester I of SMA 2 Sape Academic Year 2013/2014 is accepted. At the level of significance (confidence level) 5\% $\mathrm{t}$ count $>\mathrm{t}$ table $=3.779>2.011$.

Keywords : Quantum Learning, Learning Outcomes

\section{PENDAHULUAN}

Pembelajaran matematika seharusnya menjadi satu pelajaran yang diminati dan disenangi oleh siswa. Namun, kenyataan secara umum bahwa hasil belajar siswa pada mata pelajaran matematika masih rendah. Salah satu faktor penyebab rendahnya hasil belajar siswa pada mata pelajaran matematika, adalah metode pembelajaran yang digunakan sebagian besar guru masih bersifat tradisional. Kesulitan juga dialami oleh guru dalam memilih setrategi pembelajaran yang tepat agar siswa dapat belajar secara aktif. Hal ini disebabkan guru dalam penyampaian materi pelajaran lebih banyak menerapkan metode ceramah, dimana penyajian materi pelajaran lebih didominasi oleh guru sehingga berakibat siswa menjadi pasif dan pemahaman serta kemampuan intelektual siswa dalam menerapkan konsep matematika dalam kehidupan sehari-hari kurang diterapkan yang pada akhirnya menyebabkan rendahnya hasil belajar siswa.

Berdasarkan hasil observasi selama ini dalam pembelajaran matematika di SMA Negeri 2 Sape guru lebih banyak menggunakan metode konvensional, Pembelajaran matematika secara konvensional adalah metode atau cara untuk menyampaikan materi pelajaran secara lisan dan metode ini membuat siswa cenderung pasif, pengaturan kecepatan secara klasikal ditentukan oleh pengajar atau guru. Kurang cocok untuk pembentukan keterampilan dan sikap serta cenderung menempatkan guru sebagai otoritas terahir. Kenyataan menunjukan bahwa selama ini kebanyakan guru mengunakan model pembelajaran yang bersifat konvensional dan banyak didominasi oleh guru.

Oleh sebab itu, guru di tuntut dalam mengajar untuk kreatif khususnya mata pelajaran matematika dalam memilih metode maupun model yang tepat menjadi faktor penting agar matematika menjadi mata pelajaran yang menyenangkan dan menarik di dalam kelas. Oleh karena itu peneliti mencoba menerapkan model quantum learning, karena peneliti beranggapan bahwa model ini cocok untuk memperbaiki permasalahan yang ada di sekolah tersebut

Kemampuan siswa yang rendah dalam menyelesaikan soal matematika yang berkaitan 
dengan pemahaman konsep tentunya menjadi masalah dalam pembelajaran matematika. Faktor-faktor yang mempengaruhi pemahaman konsep belajar siswa salah satunya bisa berasal dari diri siswa itu sendiri atau dari luar siswa. Faktor dari dalam siswa misalnya kecerdasan, motivasi siswa, cara belajar dan minat yang kurang dari siswa itu sendiri. Sedangkan dari luar yaitu bisa berasal dari sarana dan prasarana, media yang digunakan dan cara penyampaian guru dalam pembelajaran. Banyak siswa yang merasa jenuh ketika sedang belajar matematika di sekolah. Kejenuhan ini membuat siswa tidak semangat dalam menerima pelajaran di sekolah.

Salah satu strategis yang tepat dalam menunjang pembelajaran yang membuat siswa aktif secara fisik dan intelektual adalah dengan pembelajaran dengan menggunakan quantum leraning adalah dimaksudkan untuk menutup kekurangan dalam gaya masing-masing siswa dalam belajar dengan pendekatan berbagai macam segi atau aspek yang ada untuk mempercepat dalam memahami dan menyerap informasi yang diberikan sesuai dengan kecenderungan siswa dalam belajar.

Menurut Huda (dalam Kurnadi, 2017) Quantum Learning merupakan model pembelajaran yang membiasakan belajar menyenangkan sehingga dapat meningkatkan minat belajar siswa dan pada akhirnya siswa dapat meningkatkan hasil belajar secara menyeluruh. Menurut DePorter \& Hernacki, 2010 (dalam Kurnadi \& Prahesti, 2017) Quantum Learning merupakan Seperangkat metode dan falsafah belajar yang terbukti efektif di sekolah dan bisnis untuk semua umur tipe orang dan segala usia. Melalui Quantum learning siswa akan diajak belajar dalam suasana yang lebih nyaman dan menyenangkan, terciptanya hubungan harmonis antara guru dan siswa akibat dari interaksi, siswa akan lebih bebas dalam menemukan berbagai pengalaman baru dalam belajarnya sehingga dapat meningkatkan pemahaman terhadap materi dan hasil belajar siswa. Selanjutnya, belajar dengan menggunakan Quantum Learning akan memberikan manfaat yaitu: 1) bersikap positif, 2) meningkatkan motivasi, 3) keterampilan seumur hidup, 4) kepercayaan diri dan 5) sukses atau hasil belajar yang meningkat.

Sehubungan dengan upaya untuk meningkatkan hasil belajar siswa dalam pembelajaran matematika tersebut salah satu model pembelajaran yang dapat diterapkan adalah Quantum Learning, dengan model ini siswa diajak untuk mengembangkan kerangka berpikir logis dengan menggunakan pola pikir matematis, artinya dengan pemilihan model pembelajaran ini akan 
mempunyai tambahan manfaat pada perkembangan pengetahuan dan pemahaman siswa terhadap konsep penting matematika.

Disamping itu model pembelajaran Quantum Learning merupakan suatu model pembelajaran yang dapat membuat siswa langsung mengalami permasalahan, menemukan sendiri jawaban atas permasalahan sesuai dengan kompetensi yang ingin dicapai. (Bobbi DePorter \& Mike Hernacki) Definisi Quantum Learning adalah interaksi-interaksi yang mengubah menjadi energi cahaya. (Musgamy. A, 2017)

Prinsip Quantum Learning adalah segalanya berbicara, segalanya bertujuan, pengalaman sebelum pemberian nama, akui setiap usaha, jika layak dipelajari maka layak pula dirayakan. Segalanya berbicara seperti halnya lingkungan kelas dan bahasa tubuh yang mengirimkan pesan untuk belajar. Segalnya bertujuan, segala sesuatu yang berhubungan dengan proses pembelajaran memiliki tujuan. Proses belajar yang paling baik terjadi ketika siswa telah mengalami informasi sebelum mereka memperoleh nama yang mereka pelajari. Ketika anak itu sudah mulai untuk belajar yang bagaimanapun untuk setiap usaha dan pekerjaan untuk belajar yang dilakukan selalu dianggap perlu dan akan berpengaruh terhadap hasil pekerjaan yang lebih baik. Apabila layak dipelajari, maka layak pula dirayakan, perayaan merupakan ungkapan kegembiraan atas keberhasilan yang diperoleh dan juga dengan perayaan dapat memberi umpan balik yang posistif.

Dari uraian di atas peneliti ingin mengangkat judul penelitian tentang "Pengaruh pendekatan quantum learning terhadap hasil belajar matematika materi pokok fungsi dan persamaan kuadrat pada kelas X SMA Negeri 2 Sape Tahun Pelajaran 2017/2018”.

\section{METODE PENELITIAN}

Campbell \& Stanley (dalam Syaiful. I, 2015) Rancangan penelitian yang digunakan penelitian ini adalah quasi experiment, yaitu metode eksperimen yang pengontrolannya dilakukan terhadap satu variabel saja, yaitu variabel yang dipandang paling dominan dalam quasi eksperimen, kontrol atau pengendalian variabel tidak bisa dilakukan secara penuh.Bertujuan untuk menjelaskan apa yang akan terjadi bila variabel-variabel tertentu dikontrol atau dimanipulasi secara tertentu. Penelitian eksperimen dapat dikatakan sebagai penelitian pengujian hipotesis yang menguji hubungan sebab akibat diantara variabel yang diteliti.

Pendekatan yang digunakan dalam penelitian ini adalah pendekatan kuantitatif. Pendekatan kuantitatif merupakan jenis pendekatan penelitian yang didasarkan atas 
perhitungan persentase, rata-rata dan perhitungan statistik lainnya. Pendekatan ini digunakan untuk mendapatkan data berupa nilai.

Nurkancana dan Sunartana (dalam Widiayana. D, 2017) Instrumen yang digunakan dalam penelitian ini adalah tes soal evaluasi yang merupakan suatu cara untuk mengadakan penilaian yang berbentuk suatu tugas atau serangkaian tugas yang harus dikerjakan oleh anak atau sekelompok anak sehingga menghasilkan suatu nilai tentang tingkah laku atau hasil anak tersebut, yang dapat dibandingkan dengan nilai yang dicapai oleh anak-anak lain atau dengan nilai standar yang ditetapkan. Adapun Untuk memperoleh data, peneliti menggunakan suatu metode, masing-masing dari metode tersebut mempunyai alat atau instrumen. Sumadi Suryabrata, 1987 (dalam Siswanto, 2006) alasan menggunakan soal essay karena dengan tes essay dapat menggali dan merangsang pemikiran/pengetahuan siswa. Tes essay akan dipersiapkan oleh peneliti. Jadi tes yang digunakan dalam penelitian berbentuk essay dengan jumlah soal 5 nomor.

\section{HASIL DAN PEMBAHASAN}

Pada penelitian ini sampel terdiri atas dua kelompok, yaitu kelompok eksperimen dan kelompok kontrol. Berdasarkan hasil analisis data kondisi awal, diperoleh bahwa kedua kelompok berdistribusi normal dan berangkat dari keadaan yang sama atau homogen. Berdasarkan hasil tersebut, pada kedua kelompok dapat dilakukan penelitian. Kedua kelompok diberi perlakuan yang berbeda, kelompok eksperimen diberi perlakuan dengan pembelajaran dengan menggunakan quantum learning. Adapun pada kelompok kontrol diberi perlekuan dengan pembelajaran menggunakan metode ceramah biasa metode konvensional. Dari jumlah populasi diambil sampel sebanyak 50 orang siswa, 25 orang siswa sebagai kelas eksperimen dan 25 orang untuk kelas kontrol. Selanjutnya sebelum melakukan uji hipotesis terlebih dahulu melakukan uji prasyarat analisis digunakan uji normalitas dan uji homogenitas dengan hasil bahwa data berdistribusi normal dan homogen.

Berdasarkan hasil perhitungan secara statistik diperoleh nilai t hitung sebesar $=3,779$, maka $\mathrm{t}$ tabelnya pada taraf signifikansi $5 \%=2,011$. Karena nilai $\mathrm{t}$ hitung lebih besar $\mathrm{t}$ tabel maka hipotesis nol (Ho) ditolak yang diajukan dalam penelitian ini yaitu "Pengaruh pendekatan quantum learning terhadap hasil belajar matematika materi pokok fungsi dan persamaan kuadrat pada kelas X SMA Negeri 2 Sape Tahun Pelajaran 2018/2019" dsis alternative (Ha) yang berbunyi ada pengaruh pendekatan quantum learning terhadap hasil 
belajar matematika materi pokok bahasan fungsi dan persamaan kuadrat siswa kelas X SMA Negeri 2 Sape Tahun Pelajaran 2017/2018.

Hasil penelitian ini menunjukkan bahwa dengan pembelajaran menggunakan quantum leraning terjadi meningkatkan hasil belajar matematika yang signifikan $5 \%$ dan $\mathrm{dk}=40$. Hal ini dapat dimengerti karena pembelajaran menggunakan quantum learning yang menekankan perlunya kesempatan bagi siswa untuk menemukan kembali matematika dengan bantuan orang dewasa (guru). Penggunaan pembelajaran quantum learnig merupakan metode pembelajaran yang mencakup aspek global atau menyeluruh. Dalam hal ini disebut juga sebagai global learning. Pendekatan global learning dimaksudakan untuk menutup kekurangan dalam gaya masing-masing siswa dalam belajar dengan pendekatan berbagai macam segi atau aspek yang ada untuk mempercepat dalam memahami dan menyerap informasi yang diberikan sesuai dengan kecenderungan siswa dalam belajar.

Dalam penelitian ini menunjukkan bahwa hasil belajar siswa yang dicobakan dengan pembelajaran menggunakan quantum learning pada kelas kontrol dan kelas eksperimen dipengaruhi oleh metode yang diterapkan. Artinya ada pengaruh pembelajaran dengan menggunakan quantum learning dapat dibuktikan dengan meningkatnya nilai rata-rata yang dihasilkan oleh kelas eksperimen setelah perlakuan dan diberikan postes diperoleh nilai ratarata sebesar 76,28 sedangkan kelas control sestelah diberikan postes hanya mencapai rata-rata 62,88 .

Rendahnya hasil belajar siswa yang menggunakan pendekatan konvensional dikarenakan pada tahap perencanaan maupun pelaksanaan pembelajaran. Siswa termotivasi untuk belajar sebagai akibat dari adanya kesadaran pada siswa bahwa matematika merupakan bagian dari kehidupan siswa itu sendiri. Siswa melihat matematika sebagai aktivitas. Matematika sebagai suatu aktivitas maka belajar matematika berarti bekerja dengan matematika dan pemecahan masalah hidup sehari-hari merupakan bagian penting dalam pembelajaran. Pada kelas kontrol guru hanya menggunakan metode ceramah terlihat siswa kurang bersemangat untuk belajar dan siswa kelihatan jenuh karena guru tidak mengaitkan matematika dengan kehidupan yang nyata dari siswa itu sendiri sehingga motivasi belajar siswa rendah dan berdampak pada rendahnya capaian nilai baik secara individu maupun ratarata kelas. Lain halnya dengan pembelajaran yang menggunakan pendekatan pembelajaran dengan menggunakan quantum learning terhadap hasil belajar matematika siswa memperoleh 
hasil belajar yang tinggi karena guru melibatkan siswa dalam aktivitas pembelajaran yang meliputi aktivitas pemecahan masalah, mencari masalah dan mengorganisasi pokok persoalan.

\section{KESIMPULAN}

Berdasarkan hasil perhitungan secara statistik diperoleh nilai t hitung sebesar $=3,779$, maka t tabelnya pada taraf signifikansi $5 \%=2,011$. Karena nilai $t$ hitung lebih besar $t$ tabel maka hipotesis nol (Ho) ditolak yang diajukan dalam penelitian ini yaitu "Pengaruh pendekatan quantum learning terhadap hasil belajar matematika materi pokok fungsi dan persamaan kuadrat pada kelas X SMA Negeri 2 Sape Tahun Pelajaran 2017/2018" sedangkan alternative (Ha) diterima yang berbunyi ada pengaruh pendekatan quantum learning terhadap hasil belajar matematika materi pokok bahasan fungsi dan persamaan kuadrat siswa kelas $\mathrm{X}$ SMA Negeri 2 Sape Tahun Pelajaran 2017/2018.

\section{REKOMENDASI}

Penelitian ini, diharapkan dapat berguna untuk kemajuan pendidikan khususnya dalam bidang pendidikan matematika. Guru dapat memadukan model pembelajaran quantum learning ini dengan model lain sesuai kebutuhan pembelajaran di dalam kelas sehingga materi dapat tersampaikan dengan baik.

\section{REFERENSI}

Musgamy, A. (2017). Quantum Learning Sebagai Proses Pembelajaran Bahasa Arab Aktif, Inovatif, Kreatif, Efektif dan Menyenangkan. (Online), Vol.6, No. 1, (http:// file:///C:/Users/USER/Downloads/4871-11111-1-PB.pdf), diakses 28 November 2017

Widiyana, D. (2017). Pengaruh Pembelajaran ARIAS (ASSURANCE, RELEVANCE, INTEREST, ASSESMENT, AND SATISFACTION), Terhadap Peningkatan Hasil Belajar KKPI Pada Kelas X SMK Negeri 1 Pedan. (Online), http://journal.unipdu.ac.id/index.php/dirasat/article/download/879/637, $\quad$ diakses 26 November 2017

Kurnadi \& Prahesti (2017). Peningkatan Kemampuan Kompetensi Strategi Matematika Siswa Melalui Model Pembelajaran. (Online), Vol.2, No.1, (https://journal.unsika.ac.id/index.php/supremum/article/download/921/912), diakses 26 November 2017 
Siswanto. (2006). Penggunaan Tes Essay Dalam Evaluasi Pembelajaran. (Online), https://journal.uny.ac.id/index.php/jpakun/article/view/864/683, diakses 26 November 2017

Setiawan.

(2008).

Pengantar

Statistik.

(Online), http://file.upi.edu/Direktori/FPBS/JUR._PEND._BAHASA_JERMAN/19590623198703 1-SETIAWAN/PS_12.pdf, diakses 26 November 2017

Indra, S. dkk, (2018). Efektivitas Team Assited Individualization Untuk Mengurangi $\begin{array}{lll}\text { Prokrastinasi Akademik. } \quad \text { (Online), http://jurnal.ar- } & \text { Ane }\end{array}$ raniry.ac.id/index.php/cobaBK/article/download/604/507, diakses 27 November 2017 